\title{
EEUROPE: GOALS, ACHIEVEMENTS, CHALLENGES AND PROSPECTS
}

\author{
Esrac Cayhan*
}

\begin{abstract}
At Lisbon, in Math 2000 , the Europear Council set the Union a new strategic gat to be reached by 2010 ; "to become the mast competitive and dynanic knowledge-based economy in the worta capable of sustainable econonic growth with more and better jobs and greater sociat cohesion." In order to realise this ambitiotis goal wo subsequent action plans have been pul into practice that sat out roatmaps of what is to be tone and by when: The a Eurape 2012 Action Plan, entorsed by the EU leaders at thetr Feira summit in June 2000 and eturope 2 ons Action man, approved by the El leaders in Seville in June 2002. This paper is going to make a general assessment of etarope withis the framework of these two Action Pans, by explaining the gonts evalwating the athievements, underling the challenges and axplaining the prospects for the fundre.
\end{abstract}

\section{Introduetion}

"EEturope is a political intiative to ensure the European Union fully benefits, for generations to come from the changes the Information Society is bringing. These changest the most significant since the industrial Revolution, are for reathing and global. They are not just about techology. They will affect averyone everywhere.

Bringing comminties, both rural and urbon, closer together, creating wealth, sharing knowledge, they have huge potential to enrich everyone" lives.

Mantaging this transfomation represents the central economic and social challenge for the Unton. It will impact profosmdly on

\footnotetext{
"Associate Prof. Dr. Duector of Akdeniz Uniwersity Catre for Stategic Reseatch, and Associate Dean of the Facilty of Economics and Adninistrative Swiences
} 


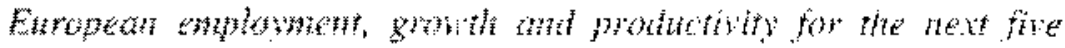
whers and for atedutes aftemats.

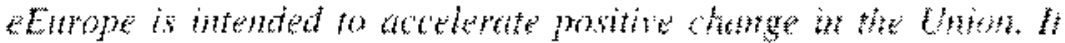

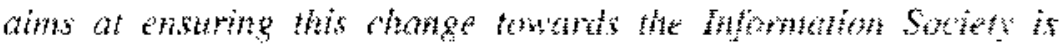

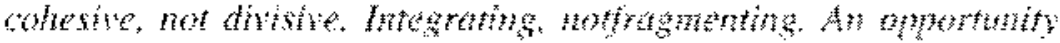

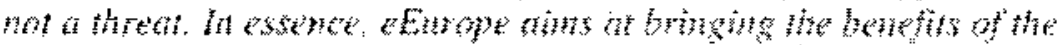

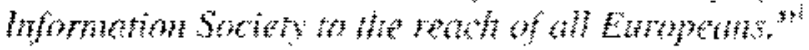

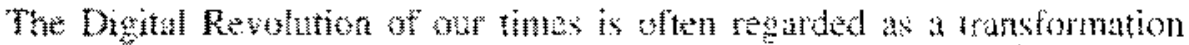
wheth ts companble the Indostrial Revolution of the $18^{\text {il }}$ and $19^{\text {th }}$

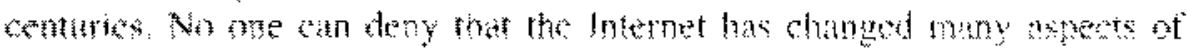
wut lives, be it in the private or the public domatin. Irformation technologies

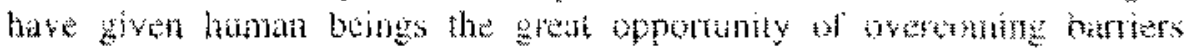
related to time and distanee.

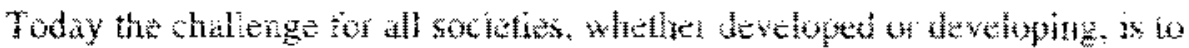
become a truly knowledge-bused economy, if is nesesary to gon the Digital Revolution. "But like all rovalitions some people will remain antouched by

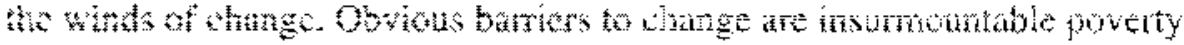
that continues to plague countries, civil and military strite and socomeultural convetions that prevent open access to the internet. ... The ahility to join the

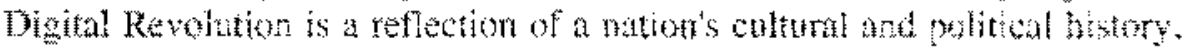
of its stability and its economy and intmotely, of the determation of its leaters and the faith of its people."

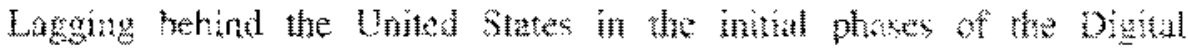
Revolution in the nineties. Lutropean leaders secided to cotch up at the

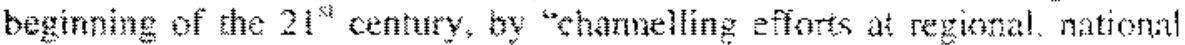

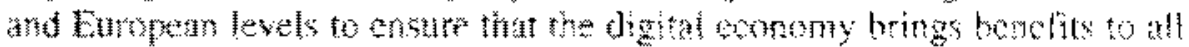
Europeancitizens and to plit a European stamp on the Internet.".

Ar Lisbon, in March 2000), the European Council set the Unon a new

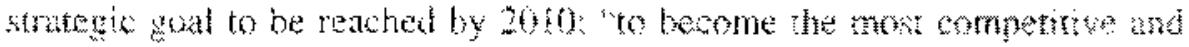

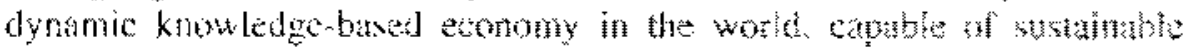

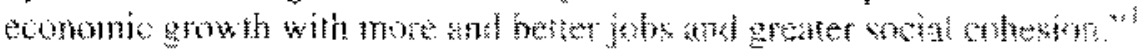

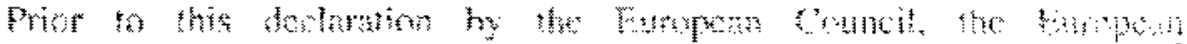

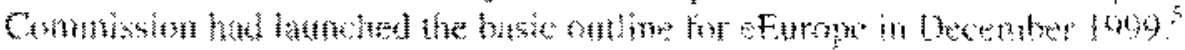

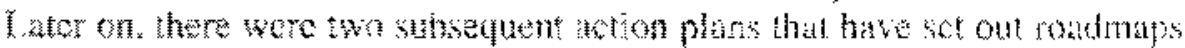

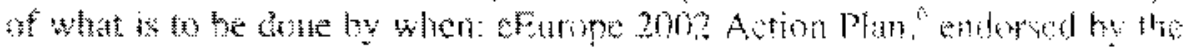


QU leaders at their Faira summit in June 2000 and eEurope 2005 Action Plan. ${ }^{7}$ approved by EU leaders in Seville in June 2002.

This paper is going to make a general assessment of eEurope, by explaining the goals and evaluating the achievements so far, within the framewark of these two Action Plans. First, eErope 2002 will be tackled by explaining the goals, analysing the achievements and underlining the challenges. Then the objectives of eEurope 2005 will be put forward as prospects for the future of information society in Europe.

\section{eEurope 2002: Goals, Achievements and Challenges}

The ongwing global transformation from industrial to information society has produced what is often termed as the "new economy", which brings new opportunities for growth and employment. The European Corrmission tackled the dynamics of the new economy as follows:

"Digital tethologins make accessing, processing storing and transmitting information intreasingly cheaper and easier. The sheer scale of information available creates luge opportunities for its exploitation through the development of new products and services. Transfoming digital infomation into economic and sociat yalue is the basis of the new economy, creating new industries, changing others and profoundly affecting thtzens' lives. Enterprises in all sectors ure storting to transform their business into ebusines: requiting restucturing of the entire company. Many sactors leg. ailines, book selling, stock brokerage, pubtishing, telecoms, computer sales) now have leading players who did not exist a few years ago. The key to their growth has been lo use the Internet to increase productivity and broaten the it network presence. All companies, big and small, need to respond to the transformation of the marketploce."

The transformation of the marketplace largely depends on consumers ability to take full advantage of the opportunities on of consumers tave to acquirc the skills that will let them access the information they seck and interact successfully on the Internet. In other words, without building consumer confidence, markets are not likely to davelop on a satisfactory leve!." 
These constentions led to the cotolusion that it was necesary to bring cveryone in Europe - every citizen. every school. every tompany, every government and administration - online as quickly as possble. It had to become commonplace to aceess afid use the Internet with the help of different technologies (computer. TV set-top box, or mobile phone). According the Commission, Furepe had to overcone the following handicaps to speed up the ugtake of digital technotogies:

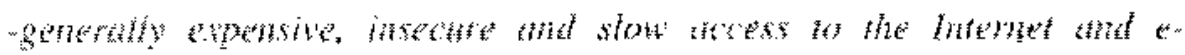

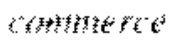

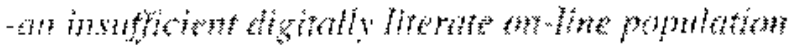

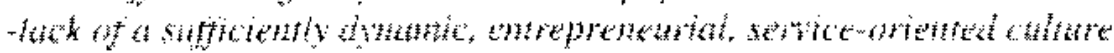

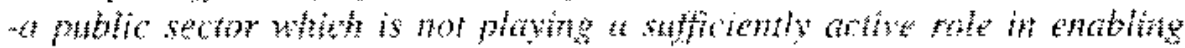

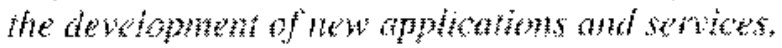

In order to ovenome these problems, the Commission's sEurope initative watd buth on 10 priority ations:

\section{Furapeat wuth into the dinital aye}

2. Citenter hoternet acess

3. Accelerating e-Commince

4. Fast Intenet for researelets and students

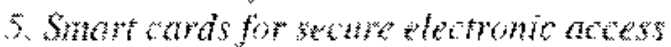

6. Nisk cuplint for high-terh SHE

7. eforticipotion for the diwabled

8. Hetheare ming

9. Intelligent moniport

10. Government online.

The Commission evaluated the eEurope inthative as another historic politual project like the singte Market and the Eurow Menber Statcs, industries and citizens were called on to join their efforts to achieve hese targets and alse to extend them to adbesion countries.

The Etumean Council teld in Lisbon on 23 and 24 Marth 2000 ,"

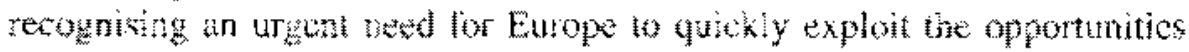

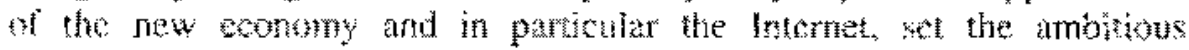
objective for Europe to become the most competitive and dymmic knnwloge-based econtmy in the walnt. in the next dectle. Following the Visbon summit, the Commission s above-mentioned 10 areas of action were rcused in the fight of the reations from the Mertor States, the Luropean 
Parliament, and the Intormal Ministerial Conference on the Information and Knowledge Society held in Lisbon on 10-11 April 200 .

Accortingly, the Commission prepared a new draft Action Plan, which sus discusced with Member States and adopted by the Feira European Council on 19-20 June 2000, The aim of this Action Plan, known as "eEurope 2002" " is to ensure that the targets set by the Lisbon European Council are reached, by defining the necestsay measures. The revised actions are cinstered aroutud three main objectives:

\section{A cheaper, faster, secure Internet \\ 2. Investing in people and skills \\ 3. Stimulating the use of the lnternet.}

The chevernent of thase abjectives requires an appropriate legal anvironment and new infrastracture and services across Europe. Also, to montot the progress towaths the knowledge based conomy, an open method of co ordination and benchmarking is to be appled. Accordingly, 23 benchmarking indicators, evaluating several aspects of the three main objectives, were discussed with Member States and endorsed by the Council on 30 November $2000 .^{10}$ On the basis of these indicators, using recent data and the same methodology for all Member States, benchmarking has bean carritud cuts."

When eEurope 2002 is cyaluated in terms of the above mentioned

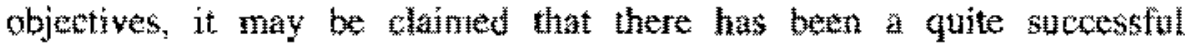
performance in generat:

Regarding theaper and faster Internet access, one of the major goals was to oreate a single market for all telecommunications services. In order to do that. rules and regulations governing Internet access had to be modemised. In March 2002, the EU fommally adopted a New Regulatory Framework for clectronic comminications network and serves, which will simplify and streamiline the existing EU legtalive famewotk. The number of laws are going to be cul down from $z$ to 8 . This new framework will be ampled in all Member States, starting from 25 July 2003. A muly liberalised talucoms market will be created, where competition cus prices and improves the quality of seryices. Thus, cheaper and faster Intemet access for citizens and business will be acheved, 
Secure Internet access has also been on the agenda of the EU. The Commission has set out comprehensive strategies for network and information security. A Framework Decision on Combating Terrorism (which includes attacks against information systems) and a Decision on Altacks against Computer Systems have been proposed by the Commission to ensure that the Member States will all take tough action against the perpetrators of serious attacks. ${ }^{20}$ Also, a 1995 FU framework Directive and a specific 1998 Directive (later modified) covering electronic communications guarantee a high level of privacy for the individual by ensuring free movement of personal data within the EU and to third countries with similar standards. ${ }^{2 !}$

According to the eEurope Benchmarking Report for $2002,{ }^{2-2}$ the porentage of EU households with Internet access went from $18 \%$ in March 2000 , up to $28 \%$ in October $2000,36 \%$ in June 2001 and $38 \%$ in December 2001. A more recent survey ${ }^{23}$ puts forward that it reached $40 \%$ by mid-2002, which is roughly equal to 150 million Internet users.

The efulno Benchmarking Report for 2002 explains that internationally atvailable statistics have shown a clear inverse relationship between Internet price and penetration. But, the objective of a cheaper internet service does not mean artificially low or subsidised prices. The approach of eEurope is to stimulate competition so that prices will go down to competitive levels away from monopoly prices. "This bas proved successful as regards Internet access by a standard dial-up telephone line. Prices for Internet access by standard telephone have been going down continuously and substantially in the last two years. A Commission survey, carred out in November 2001, found that for a typical residential user, i.e. 20 hours of usage off-peak, monthly costs are now between 10-20 Euros for the cheapest offer in most Member States, including call charges. Thus, the marginal costs of Internet access for a PC owner have become small, but still remain significantly higher than in the United States. "‥-

In short, remarkable steps have been taken to develop cheaper, faster and secure Internet access. Similarly, there has been signilicant progress in terms of investing in people and skills. While Member States organise their own mational eduction systems, the EU's eLeaning Action Plan for 2 my2004, co-ordinates national efforts to modernise educational and vocational training systems. The eLeaning Action Plan has the following objectives: 
-to ensure, by the end of 2003, that all school-leavers have had the chance to become digitally literate

-to provide all teachers with appropriate training, to adapt teacher training programmes accordingly, and to introduce measures to encourage teachers to make real use of digital technology in their lessons, by the end of 2002 -to offer every worker the opportunity to become digitally literate through the lifelong learning system, by the end of 2003.

Computer literate school leavers and workers are expected to keep up with the Intemet revolution in their workplaces. This means a highly skilled working force to be employed and digitally literate consumers to buy new products and services. ${ }^{26}$ The intention is to make lifelong learning the driving force behind a cohesive and inclusive society, within a competitive economy. Such an attitude will help promote the objectives of employability and adaptability, overcome the shortage of skills associated with new technologies, and improve social inclusion. ${ }^{27}$

Internet access for schools went from $89 \%$ in 2001 up to $93 \%$ in 2002 . $^{28}$ Although the major target of providing all schools with Internet access by the end of $2001^{29}$ could not be achieved, the progress so far is still remarkable. When it comes to the ratio of students to online computers, the recent goal was set in March 2002. At their summit in Barcelona in March $2002,{ }^{30}$ the EU's heads of state and government set themselves the target of ensuring that, by the end of 2003 , there would be one online computer, used for educational purposes, for every 15 pupils in EU schools. In 2001, the ratio was one online computer for every 25 students, which went down to one for every 17 in 2002 . $^{3 f}$

In the workplace, the people of Europe are to be in a position to acquire new knowledge and skills to ensure future employability. The objective is to enable them with such skills at any time in their lives. This guarantee of life-long learning makes e-inclusion possible, which is of crucial importance to the European social model. Member States agree that it is their responsibility to make benefits of information and communication technologies available to everyone, rather than to a privileged minority. Internet access is regarded as a fundamental right for all citizens and governments are supposed to have a duty to provide it. In other words, the EU is detennined to make the new knowledge-based society inclusive for all European citizens. 


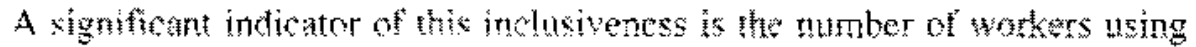
comptates at their workplace. "By 2002 , more that hat of EU wonkers were tustng computers at their workplace, and this has grown by about a fiftu

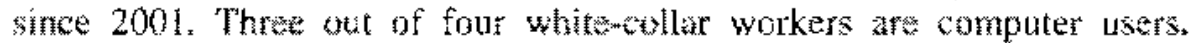
However, not enowgh people are receiving the necesury traning: only about a thim of the EU wothere has ever hat computer training far a job.

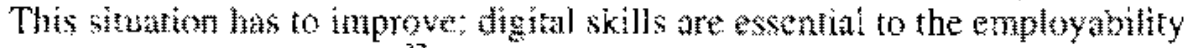
of wotkers in all sectors.

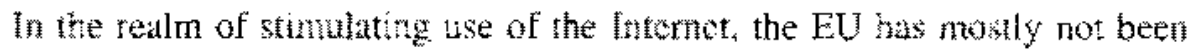

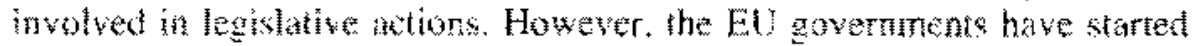

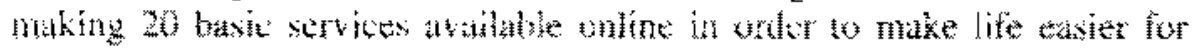

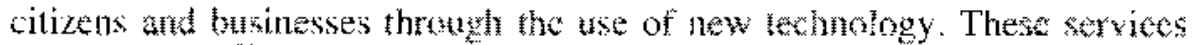
are as followas:

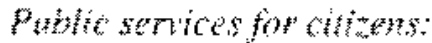

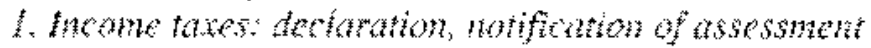

3. Job searth services by labolit offices

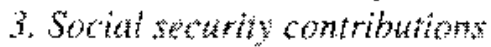

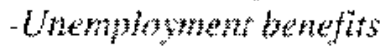

- Family antowates

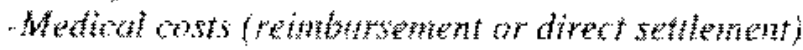

Stumengrants

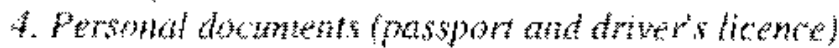

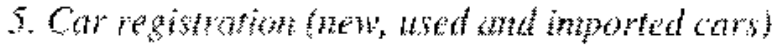

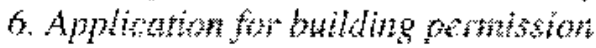

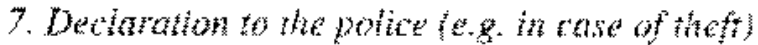

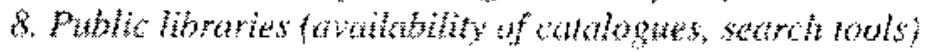

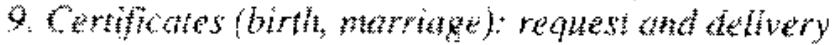

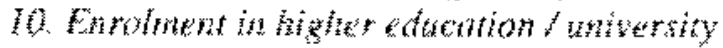

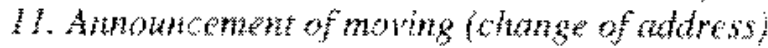

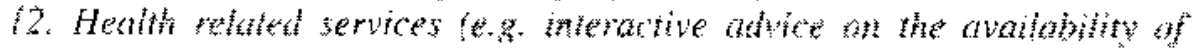

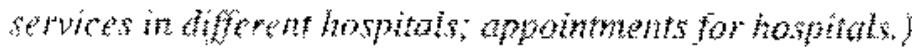

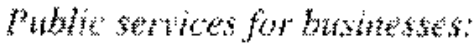

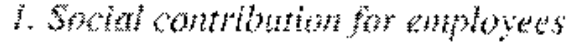

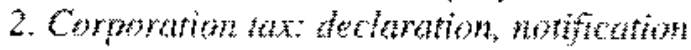

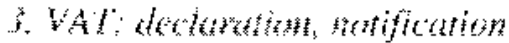

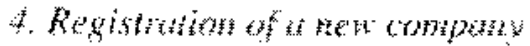

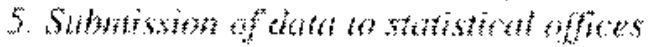

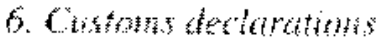




\section{Environment-related permits (incl. reporting)}

\section{Public procurement.}

In April 2002, research carried out for the European Commission ${ }^{34}$ showed that, on average, $55 \%$ of basic public services were available online compared to $45 \%$ in October 2001. Most of the websites surveyed already provide more interactivity than simply downloading forms. The research also reveals that the provision of eGovernment services to business $(68 \%)$ is progressing much faster than to citizens $(47 \%)$, with the only exception of the Netherlands where online public services to citizens are more widespread than services to business.

In order to identify common trends within groups of related services, four service clusters have been created: ${ }^{35}$

-Income-generating: services where finance flows from citizens and businesses to the government (mainly taxes and social contributions)

-Registration: services related to recording object -or person- related data as a result of administrative obligations

-Returns: public services given to citizens and businesses in retum for taxes and contributions

-Permits \& licences: documents provided by govermmental bodies giving permission to build a house, to run a business etc.

Services which involve paying money to the public sector remain the highest performer with a $79 \%$ rate in April 2002 compared to $62 \%$ in October 2001. Of these services, VAT declarations have the highest score $(88 \%)$. Overall, Ireland has the highest score $(85 \%)$ followed by Sweden $(81 \%)$, Finland $(70 \%)$ and Denmark $(69 \%)$, which means that many of their services reached a full transactional phase. All the other countries score between $22 \%$ and $70 \%$. The average scores of each country are progressing with a variation between $4 \%-20 \%{ }^{36}$

To stimulate the use of the Intemet in commercial activities, the EU has concentrated on providing a favourable environment in which companies and all other types of organisations can develop digital skills and services. For example, a legal framework for eCommerce has been set out in a Directive $^{37}$ which became law throughout the EU in January 2002. In March 2002 the formal decision was taken to create the ".eu" top level domain which will allow European citizens, organisations and businesses to have 


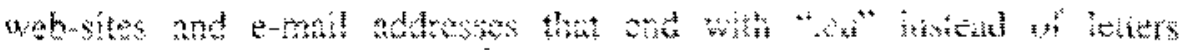
indicating a country or "enten

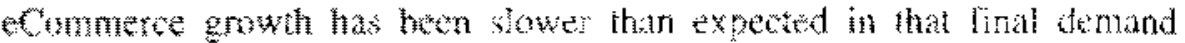

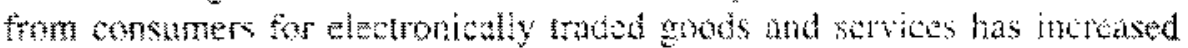

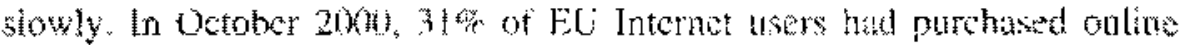

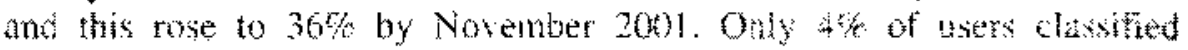

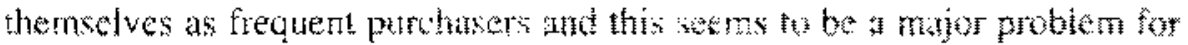

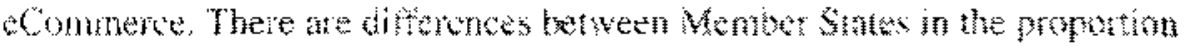

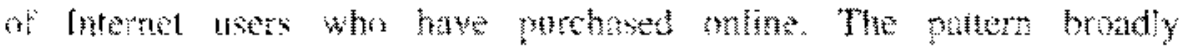

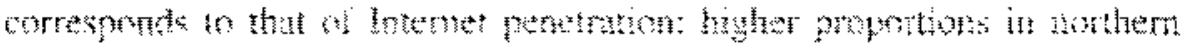

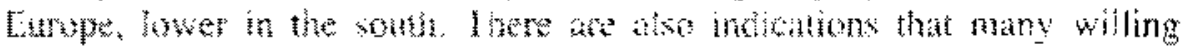

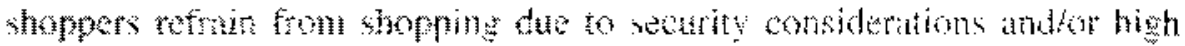

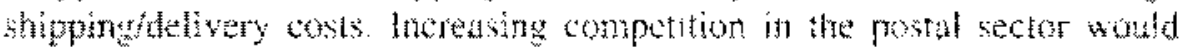

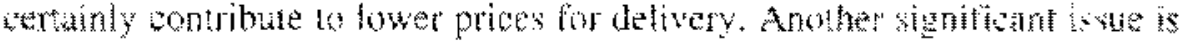

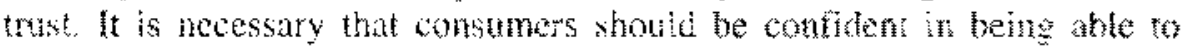
obtain redress in the sent of an ondine dispute

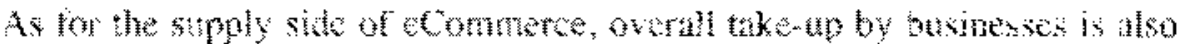

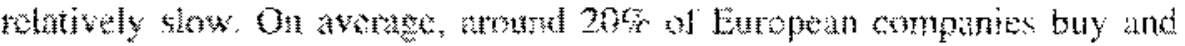

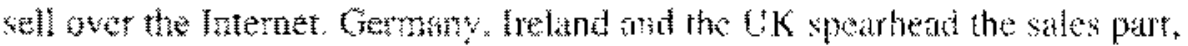

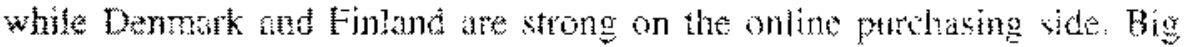

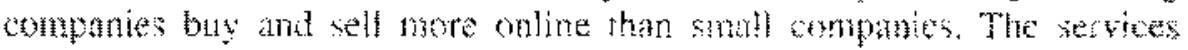

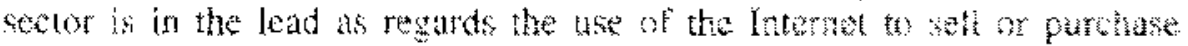

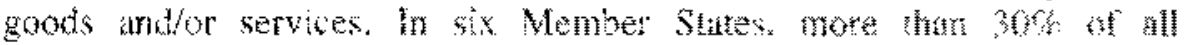

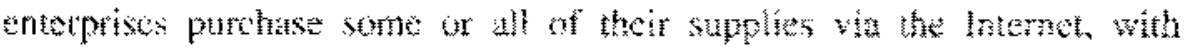

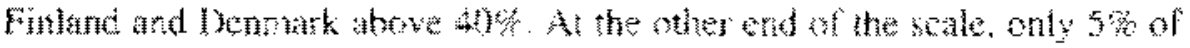

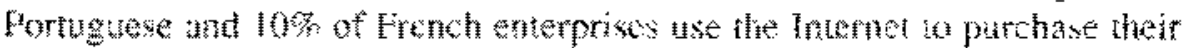

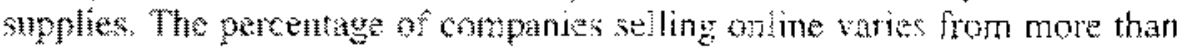

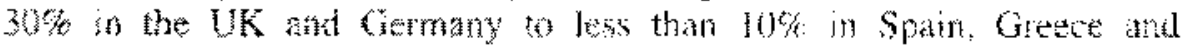

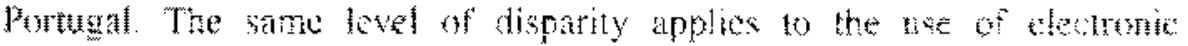

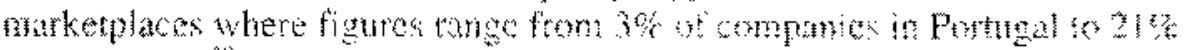
in Cichanat.

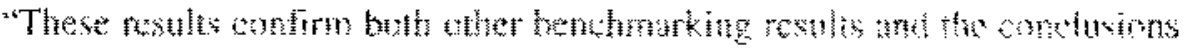

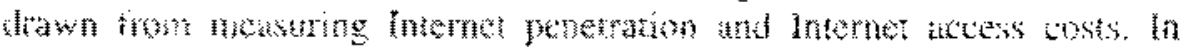

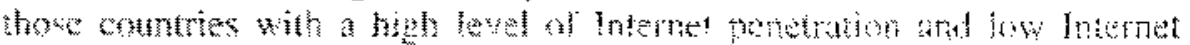

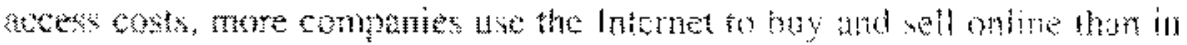

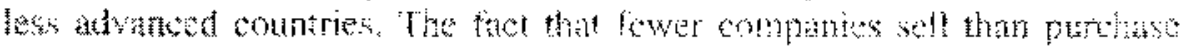

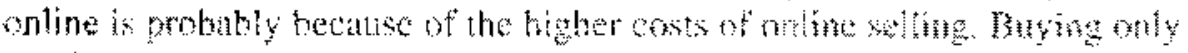

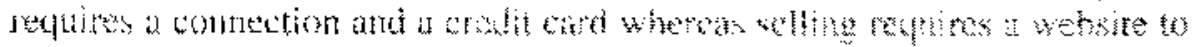


be set-up and maintained with adequate security and possibly logistics organisation." 40

nd

ed

ne

Another initiative, eHealth, aims to use digital technologies to improve the quality and accessibility of health services, including e-accessibility for the disabled. In March 2002, the EU Council of Ministers adopted a Resolution ${ }^{41}$ designed to facilitate Internet access for 37 million disabled people in Europe by agreeing a set of internationally recognised standards. The Resolution also calls on Member States and the Commission to establish a permanent dialogue with organisations representing disabled persons and organisations representing the elderly to take account of their comments and concerns.

At the same time, there has been considerable progress in Internet take-up by general practitioner doctors. In June $2001,60 \%$ of all primary care providers were equipped with an Intemet connection, compared to $48 \%$ in May 2000. Over the same period, the percentage of general practitioners using the Internet to communicate with patients rose from $12 \%$ to $34 \%{ }^{42}$

The EU's performance regarding the eEurope 2002 Action Plan has been successful. However, since 2000 , the situation has evolved in such a way that, while some measures have been completed, some new challenges have emerged. So the second Action Plan eEurope 2005 has updated the EU's priorities and fine-tuned the process. The next section will explain the Union's future plans regarding information society by concentrating on eEurope 2005.

\section{eEurope 2005: Prospects for the Future}

Some objectives of eEurope have been achieved in that Internet access costs are going down. The marginal costs of Internet acccss for a PC owner have become small. However, they are still higher than in the United States. Slow eCommerce development and difficult broadband deployment are also important problems that should be solved. ${ }^{43}$

In order to tackle the remaining problems, Member States have agreed upon the principles of eEurope 2005 Action Plan, which is based on two groups of actions that reinforce each other. "On the one hand, it aims to stimulate services, applications and content, covering both online public services and e-business; on the other hand it addresses the underlying broadband infrastructure and security matters." 44 
To facilitate broadband access ${ }^{45}$ in remote and rural regions, Member States are to use the EU's existing Structural Funds (regional and social funds). At the same time, they should eliminate legislative barriers and promote investments in broadband. By mid-2003, a Cyber Security Task Force (CSTF) is to start working as a centre of competence on security questions.

While tackling infrastructure and security matters, eEurope 2005 also aims at the effective use of the Internet for eCommerce and public services, including schools and businesses. In other words, enhancement of eGovernment, eLearning, eHealth and creation of a dynumic environment for the development of eBusiness are the major priorities.

As for eGovernment, by the end of 2003 , the Comnission will put forward an interoperability framework involving common technical specifications to ensure that national eGovernment services can be delivered to citizens and businesses throughout the European Union. By the end of 2004, EU governments will ensure that 20 basic services are ayailable online, interactively. This must include guaranteed access for citizens with special needs. By the end of 2005, the EU Member States will carry out a significant portion of their public procurement electronically. ${ }^{46}$

eLcarning is to be enhanced by the Member States. By the end of 2002, the EU should have in place an cLcarning Programme to implement the eLearning Action Plan in 2004-2006. All schools and universities should have broadband access by the end of 2005 . By the end of 2003, EU governments should launch training programmes to provide adults wilh the skills they need for employment in the knowledge society. ${ }^{47}$

Regarding eHealth, by spning 2003, the European Commission will propose the introduction of electronic health cards based on common standards and exchange of best practice. By the end of 2005, EU governments are going to develop health information networks linking hospitals, laboratories and homes. By the end of 2005, the European Commission and EU governments will cnsure the online provision of health services, including information on healthy living, illness prevention and electronic health records. ${ }^{+8}$

eBusiness will be tackled in a summit which is to take place in 2003 to give high-level business representatives the opportunity to describe the difficulties encountered when doing eBusiness. By the end of 2003, the Commission will set up an eBusiness support network to promote the take 
up of digilal technologies and processes by small and medium sizat businesses. By the end of 2003, the private sector has to develop interoperable eBusiness solutions for transactions, security, signatures, procurement and payments. By the end of 2003, the Commisson will examine possible ways of selting an an EU wide online dispute resolution system.

The priortics of eEurop 2005 Action Plan show that by 2005 , Europe is expected to have modern online public services and a dynamic eBusiness enyiromment. As ar enabler for hese aims, there should be widespread avaulabulity of broadband access at compesitive pricks, and a secure infommation infrastructure.

\section{Conclusion}

Whan Eu leaders dectuded to make the Euruesan Union the wond's most competitive knowledge-based society by 2010 at Lisbon in Marwh 2000 , they agreed that bosinesses and citizens must have acoses to an inexpensive, wote-class communications infrastructure and a wide range of servioes; every cinzen must be cantipped with the skils needed to live and work in this new information soctery, and, a higher priortity must be given to lifelong learning as a basic component of the European sociat model.

Accordingly, eEurope 2002 Action Plan has put forward broad objectives and successully put the Internet at the top of the European putitical agenda. Significant progress has been made regarding a cheaper, faster, and mote secure Intemet; investing in peopite and skills; and, stimulating the use of the Intermet. However, new challenges emerged and in ordor to cope with them. the efurope 2005 Action Plan has narrowed the focus; concentrating on effective access, usage and the ready availability of the Internet.

Europe 2005 puts users at the centre, because the new knowledge-based saciety must be an inclusive one. At all tevels and in all implementing

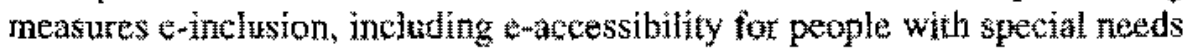
is emphasised. Emuchusion means that key services must be avatable not only via personal computer but also vitu interactive digital television, third generation mobile phones and cable newwors. eGovemment, searning, eHealth and eBusiness are expexted to proseress on a secure broadband infrastructenge throughout the Union by 2005 . 
"The EV eftor is designed ta buitd on and wo stemgthen the "European scial modei", Mcluding a high level of social protection. It is aiso meant to preserve Europe's cuntural and linguistic diversity. It foctuses on developing Eurypean content in Etropesn langunges so that everybody las access to services and content in theit own mother tongue. The Internet anay turn the world into a global village, but the EU is committed to ensuring that in this village every culture and every langutage maintains its role at local level.,

The eEurope intiative has albo becone part of the enlargoment proess of the Union. Social industion is vital to the sucess of future enlargement, and digital inctusion is an impuntant aspect of it. "At the Eutopean Ministerial Conference huld an Warsaw bu $11-12$ Hay 2000 , Central and Eastern European Countries recognisel the strategic goal set by the EU.15 in Lisbon and agreed to entarte the challenge set by the EU-15 whth eEuroge ard decided to launch an eEtrope-like Acton Plats' by and for the Candidate Couniries as a compliment to the EU political commiments in order to try and broaden the base for achiaving the ambitious above mentioned goal. In Febuary 200I, the Europen Commissin invited Cypuss. Malta and Turkay to join the other cantulate countries in defining this common Action Plan." 3 is

This initiative, "eEumope $2603 t$ ", of whist Turkey is a part, "mirrors the priority objextres and tarets of etrope but provides for attons which tackle the spcoific situation of theCandidate Countres. It shouta not be perceived as a substitute for or interetering with accession negotiations. Like eEurope, the eEuropet Action plan ams to acelerate reform and modenisation of the sonomes in the comdthate countries, encoutage capacity and institution buhimg, improve overal competitiveness and provide for actions whoth address the spectic situation of the Candilate Countries.

The EU's eEtroge initiative, which has been adomed by the candidate countries as woll, was designed as a means of getting furope onlinc as quickly as possible. "It also whes the Intumet a Europent dimention by encouraging muli-lingual content ant by allowing Luropean countries to build on their cumpetilive advantages in areas such as mobile phome technologes and digital television. Acheving the elumope gouts will certanty help aste jubs and inake European mastries more competitive. This is part af the EU"s continumg efforts to fultil its oblutation - enchined in Article 2 of the Trealy on European Luton - io promote domomic and soctal poogres and a high level of employmont. The sueces ot eEurope 
depends not only on the European institutions but on national, regional and local govermment throughout the EU, on businesses, schools, hospitals." ${ }^{53}$ In fact, it depends on European citizens, since eEurope has been designed for them. That means the citizens of Europe should try to take advantage of it and make it work for themselves.

\section{Endnotes}

11 "eEurope: An Information Society For All", Communication on a Commission Initiative for the Special European Council of Lisbon, 23 and 24 March 2000, p.2, http://www.europa.eu.intinfornation society/eeurope/news_library/gdf files/initiat ive_en.pdf, access date: 11102002 .

${ }^{2}$ Darby Patterson, "Point of View: Gaining an International Perspective", Government Technology, August 2002, http://www govtech net/magazine/story.phtm1?id=3030000000018386.0, access date: 06112002 .

3 "Towards a knowledge-based Europe: The European Union and the information society",

Manuscript for information brochure for the general public, European Conmission, Directorate General for Press and Communication, October 2002, p.4, http://europa.eu,int/infonmation_society/newsroom/documents/catalogue_en.pdf, access date: 30102002.

4 "Presidency Conclusions: Lisbon European Council", 23 and 24 March 2000, http://ue.eu.int/en/Info/eurocouncil/index.htm, access date:15 112002.

5 "eEurope: An Information Society For All", see, no.1 above.

6 "eEurope 2002: An Information Society For All", Action Plan prepared by the Council and the European Commission for the Feira European Council, 19-20 June 2000. Council of the European Union Commission of the European Communities, 14.6.2000,

http://www.europa.eu.int/information_society/ceurope/action plan/pdf/actionplan_e n.pdf, access date: 11102002 .

7 "eEurope 2005: An information society for all", An Action Plan to be presented in view of the Sevilla European Council, 21/22 June 2002, Communication from the Commission to the Council, the European.Parliament, the Economic and Social Committee and the Committee of the Regions, 28.5.2002, 


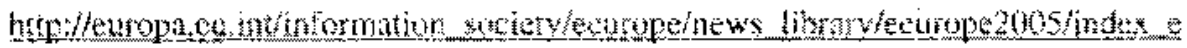
n.tgren, acess date: 02102002 .

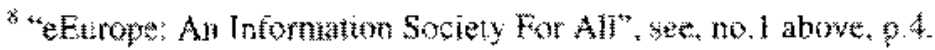

"Bid.

"Mbik. p.5.

"Ibid.

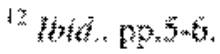

${ }^{19}$ Sew, no. 4 abxy

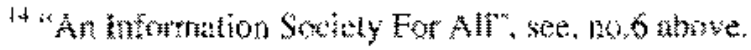

"W:4., p.2.

Detals of these refing are as follow:

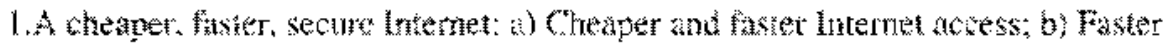
Internet for researchess and stadent; o) Secure netronks and smart cards.

2. Irvesting in peoples and skits: a) Entopean youth into the digital ayst: b) Working in the knowledge-based ceonomy; 5 Participation ter all in the knowled ge-based sconorny.

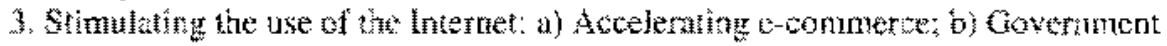
anline: electronic atess ta pubic servicer; c) Health online; d) European digital cantent for global wetworks: el htclligett iansport systens.

it See.

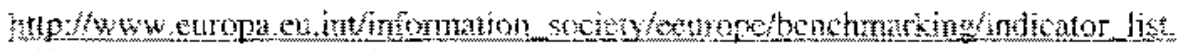
tyif access date: 101026002 .

The 23 trenchmating indicaiors are:

Cheaper, fuster internet

1. Parcentage of population tho regularly use the tnernct

2. Percentage of howseholds with internet acesest al home

3. Internet access costs

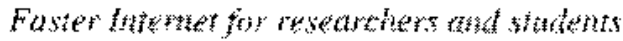

4. Sped of interconectons and servees available berween and within national

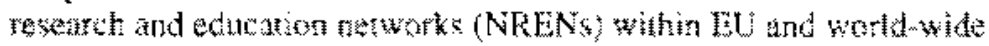

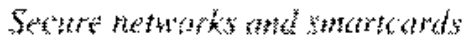

5. Number of secure servers per millon inhabitant:

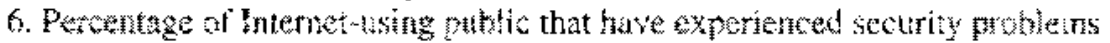

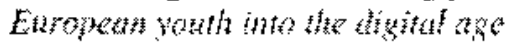

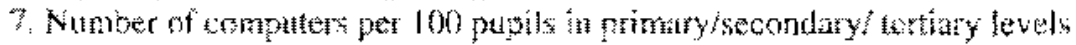


8. Number of computers connected to the Internet per 100 pupils in primary/secondary/ tertiary levels

9. Number of computers with high speed connections to the Internet per 100 pupils in primary/secondary/tertiary levels

10. Percentage of teachers using the Intemet for non-computing teaching on a regular basis Working in the knowledge-based economy

11. Percentage of workferce with (at least) basic IT training

12. Number of places and graduates in ICT related third level education

13. Percentage of workforce using telework

Participation for all in the knowledge-based economy

14. Number of Public Internet Points (PIAP) per 1000 inhabitants

15. Percentage of central govemment websites that conform to the WAI accessibility

gnidelines at A level

Accelerating e-commerce

16. Percentage of companies that buy and sell over the Internet

Government on-line

17. Percentage of basic public services available on-line

18. Public use of govemment on-line services - for information/ for submission of forms

19. Percentage of public procurement which can be carried out on-line

Health on-line

20. Percentage of health professionals with Internet access

21. Use of different categories of web content by health professionals

European digital content for global networks

22. Percentage of EU web sites in the national top 50 visited

Intelligent Transport Systems

23. Percentage of the motorway network (vs, total length of network) equipped with congestion information and management systems.

17 "eEurope Benchmarking Report: eEurope 2002", Communication from the Commission to the Council, the European Parliament, the Economic and Social Committee and the Committee of the Regions, 5.2.2002, COM(2002) 62 Final, http//www.europa.eu.int/information society/eeurope/news_library/new document s/benchmarking/benchmarkin_en.pdf, p. 4, access date: 10102002.

${ }^{18}$ For details, see, http:/www.europa.eu.int/information_soclety/topics/telecoms/regulatory/new_rf/in dex_en.htm, access date: 12112002. 


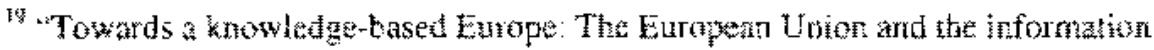
sacity", sea, no. 3 athere.

30

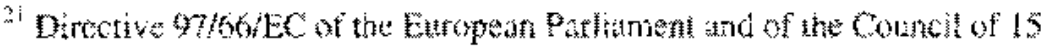

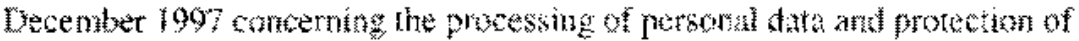

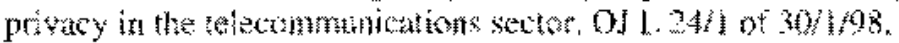

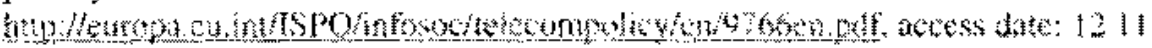
20122.

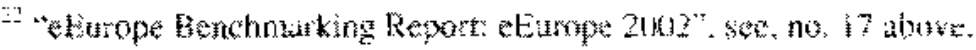

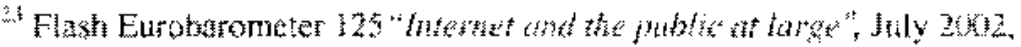

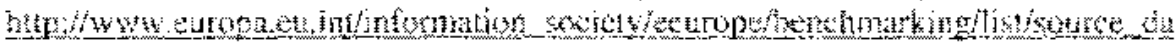

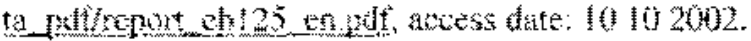

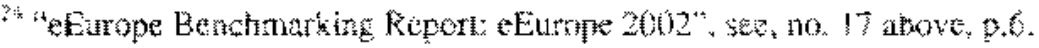

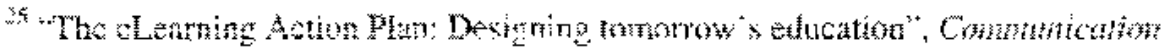

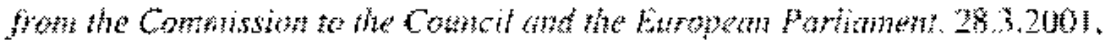

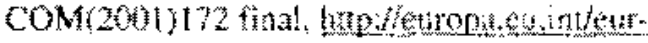

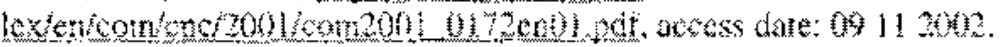

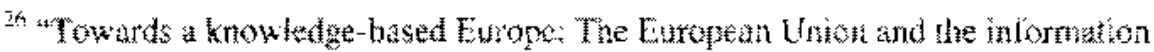
society" sate, no, whove. p.to.

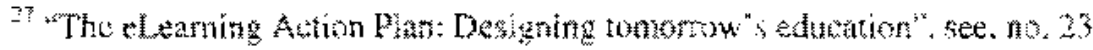
sibove P. 2 .

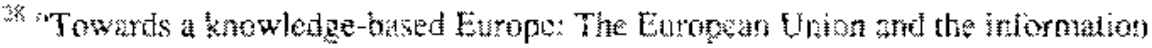
sosity

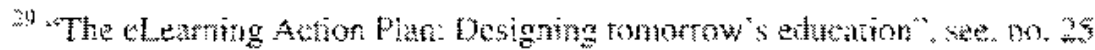
above, p. 3 .

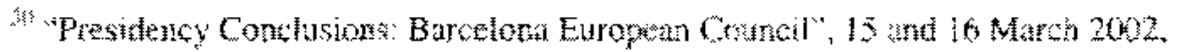

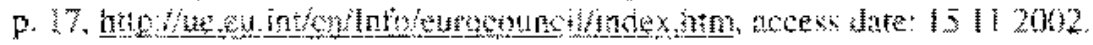

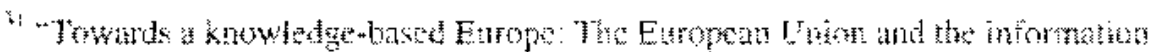

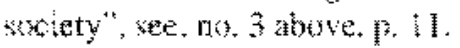

"Fild. 
${ }^{33}$ Ibid., pp.12-13.

34 "Summary Report: Web-based Survey on Electronic Public Services (Results of the second measurement: April 2002)", European Commission DG Information Society, htpp:/www.europa.eu.in/information society/eeurope/benchmarking/list/source_da ta pdf/2 $2^{\text {nd }}$ measurement final_report.pdf, access date: 1010 2002, p.4-5.

${ }^{35}$ Ibid., p. 5.

${ }^{36}$ Ibid., pp. 5-8.

${ }^{37}$ Directive 2000/31/EC of the European Parliament and of the Council of 8 June 2000 on certain legal aspects of information society services, in particular electronic commerce, in the Internal Market ("Directive on electronic commerce"), OJ L 178/1 of 17.7 .2000 , http:/europa.eu.int/ISPO/ecommerce/legal/documents/2000_31ec/2000_31ec_en.p df, access date: 17112002 .

38 "Towards a knowledge-based Europe: The European Union and the information society", see, no. 3 above, p. 11.

${ }^{39}$ Ibid., p. 14.

${ }^{40} \mathrm{Ibid}$.

41 "Accessibility of public web sites - aecess for people with disabilities", Council Resolution, $2420^{\text {th }}$ Council meeting: Transport and Telecommunications, 25/26 March 2002, p. 9, http//ue.cu.int/Newsroom/makeFrame,asp?MAX=1\&BID=87\&DID=70046\&LAN G=1\&File=/pressData/en/trans/70046.pdf\&Picture=0, access date: 17112002 .

42 "eEurope Benchmarking Report: eEurope 2002", see, no. 17 above, p. 16.

43 "Towards a knowledge-based Europe: The European Union and the information society", see, no. 3 above, p. 15.

44 "eEurope 2005: An information society for all", see, no. 7 above, p. 3.

${ }^{45}$ The high-speed transmission of voice, data and video signals over fixed or mobile networks. These networks include fixed-wireless, fibre optics and satellite links, and will also include third-generation mobile phones when these become widely used 


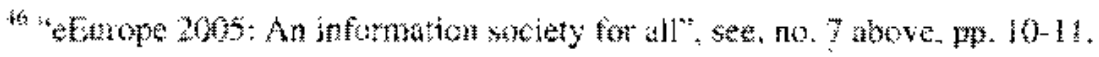

Hbid, , I?

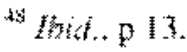

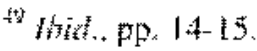

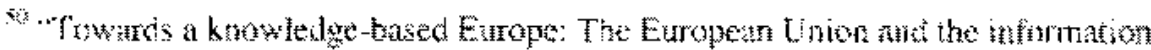

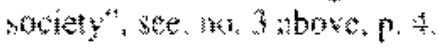

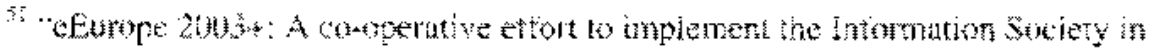

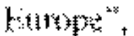

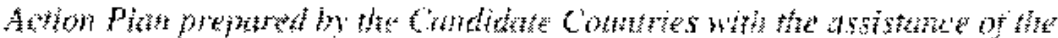

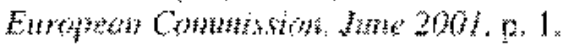

Mle $20) / 2$

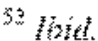

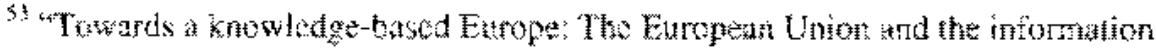

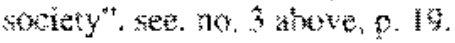

